\title{
Mobile Phone: Sejarah, Tuntutan Kebutuhan Komunikasi, Hingga Prestise.
}

\author{
G. Yasser Art.
}

Fakultas Dakwah dan Komunikasi IAIN Antasari

\begin{abstract}
Human desire to keep on communicating bulldoze constraints of time and space in turn trigger an attempt to create a tool to bridge the limitations of earlier. The codes are transmitted in the conventional form of simple visual and sound that still leaves human dissatisfaction remote communication (tele-communication), effectiveness and efficiency of the smoke, sound, sign of morse, certainly not yet enough. Jump skip the age, and found the telegraph to the appearance of the phone (cable) ago cordless phone which then called the cell phone (mobile phone) is then transformed into revolution. These evolution then became revolution of functions and capabilities that are owned by the cell phone. The sophisticated of mobile phone technology finaly push it not just as a phone but far beyond that, also its additional functions. Which should be recognized and taken into account is the impact of which was carrying was also becoming more sophisticated.
\end{abstract}

Keywords: communication, telecommunication, cellular phone, technology.

Hasrat manusia untuk tetap dapat berkomunikasi melibas kendala batasan ruang dan waktu pada akhirnya memicu usaha untuk menciptakan alat untuk menjembatani keterbatasan tadi. Kode-kode yang dikirimkan secara konvensional berupa visual dan suara yg sederhana masih menyisakan ketidakpuasan komunikasi jarak jauh manusia, efektifitas dan efisiensi pada asap, bunyi, tanda morse, tentu belumlah cukup. Sedikit melompati masa, lalu ditemukan telegraf hingga kemunculan telepon (kabel) kemudian telepon tanpa kabel yang kemudian disebut ponsel (telepon selular). Evolusi ini kemudian berubah revolusi fungsi dan kemampuan yang dimiliki oleh ponsel. Kecanggihan teknologi mendorongnya menjadi selain fungsi bukan hanya sekadar telepon tapi juga fungsi tambahannya. Kesadaran dan yang perlu dipertimbangkan adalah dampak yang dibawanya pun juga semakin canggih.

Kata kunci: komunikasi, telekomunikasi, telepon selular, teknologi.

Secara umum semua manusia dalam kehidupannya memerlukan interaksi dengan orang-orang sekitarnya atau lingkungannya, baik itu di tingkat individu, organisasi hingga pada tingkat khalayak ramai. Interaksi dalam bentuk komunikasi dapat berlangsung secara langsung, directly berhadap-hadapan, artinya tanpa ada medium peralatan perantara atau dapat juga dengan menggunakan suatu perangkat tertentu yang mempunyai fungsi tertentu pula. Fungsi perangkat (medium) tersebut adalah untuk memecahkan kendala dan memperlancar proses

Email penulis:

Alhadharah Jurnal Ilmu Dakwah Vol. 15 No. 30, Juli-Desember 2016, 71-88 
komunikasi tersebut, misalnya untuk dapat menaklukkan permasalahan batasan ruang, jarak bahkan waktu. ${ }^{1}$

Sejak dimulainya awal peradaban manusia, sejak itu pula manusia berupaya sekuat tenaga untuk menciptakan pelbagai penemuan alat-alat yang dapat menunjang proses komunikasi mereka dengan sekitarnya, mulai dari metode kuno kepulan asap hingga metode paling anyar secanggih telekomunikasi reality visualisasi hologram 3 dimensi. Begitulah kira-kira perkembangan undagi manusia selama ribuan tahun yang dijelaskan singkat hanya dengan satu kalimat di atas saja.

Teknologi diciptaan manusia untuk mempermudah manusia dalam berkomunikasi dengan yang manusia lainnya, dalam hal ini adalah teknologi komunikasi. Teknologi komunikasi memang dapat dengan mudah diartikan sebagai fisiknya atau perangkat kerasnya pada struktur organisasi yang mempunyai nilainilai sosial, setiap orang dapat mengumpulkan dan memproses serta saling bertukar informasi juga berhubungan dengan orang-orang. ${ }^{2}$

Handphone/mobilephone atau telepon seluler atau telepon genggam dalam bahasa Indonesia adalah salah satu produk teknologi komunikasi dalam bentangan kronologi invent-invent di atas. Sesuai namanya, telepon genggam merupakan 'anak cucu' dari telepon, dengan pengertian telepon sebagai perangkat yang berkabel dan statis (terbatas sesuai kabel), sedangkan telepon genggam adalah penemuan selanjutnya setelah telepon. Jadi telepon genggam tidak saja pula sesuai namanya (genggam), tapi juga telepon genggam bersifat dinamis karena koneksinya menggunakan gelombang frekuensi atau tanpa kabel (nirkabel) atau lazim disebut wireless.

Dalam guliran waktu telepon genggam itu sendiri terus bermutasi menuju bentuk yang beragam semakin canggih. Mirip dengan televisi, dahulu layar telepon genggam hanyalah layar dengan display yang hitam putih saja (monochrome/dua warna saja, ada juga yang hijau/orange/merah/ dan hitam) dan juga sempit serta kasar (tidak detil), tapi sekarang layar telepon sudah berwarna dan sangat detil dan jernih berkat GPU (Graphic Processing Unit) yang canggih, semisal Andreno. Kalau sebelumnya true color dengan 265.000 sudah luar biasa bening sekarang HDD (high definition display) nyaris 17.000.000 warna dengan tingkat resolusi layar yang bukan main tingginya, 2592 x 1944 pixels (bisa mengalahkan resolusi sebuah layar monitor komputer sekalipun, yang kebanyakan 1920 x 1200 pixels). Telepon genggam sekarang ini juga diberi 'otak' secanggih komputer, misalnya pada merk LeTv seri LeMaxPro atau Xiaomi seri Mi5 dengan prosesor Chipset Qoalcomm Snapdragon berkecepatan $2,2 \mathrm{GHz}$ (nyaris setara mesin-mesin Intel core dan AMD A). Dukungan media penyimpanannyapun tidak main-main, tertanam memori sebesar 128 Gb pada Samsung S6-S7, iPhone 6 plus, dan Asus ZenFone Zoom. Itu

\footnotetext{
${ }^{1}$ Stephen W Littlejohn, Theories Of Human Communication, (Thompson: Wardsworth, 2004), hal. 279.

2 Everette M. Rogers, Communication Technology: The New Media in Society, (London: Collier Macmillan Publisher, 1986), hal. 2.
} 
pun belum ditambah memory eksternal yang bisa mendongkrak ruang simpan sampai $512 \mathrm{~Gb}^{3}$. Urusan RAM penunjang kinerja smarphone sekarang sudah tersedia RAM kapasitas raksasa $6 \mathrm{~Gb}$, seperti ditanamkan pada vendor Vivo Xplay 5. Beberapa telepon genggam berotak cerdas (cepat), selanjutnya kemudian disebut 'smartphone' ini juga menjalankan Sistem Operasi yang biasa diterapkan oleh komputer, seperti Windows Ce (Celular) sebagaimana pada Nokia seri Asha atau C7, bahkan sekarang komputer yang mengadopsi OS (Operating System) telepon genggam seperti software BlueStack yang menjembatani Windows dengan Android, beberapa pabrikan laptop bahkan menyediakan adaptasi OS Android sedari awal booting. Hampir semua vendor perusahaan telepon genggam di dunia sudah menandatangi kontrak kerjasama dengan perusahaan raksasa software Microsoft sebagai sistem operasi yang dominan dunia komputer, seperti perusahaan vendor asal Korea Samsung yang mengeluarkan tantangan high end Blackberry atau Nokia seri X yakni Omnia II yang bersistem operasi Windows Mobile V 6.5 Professional (beberapa tipe telepon genggam juga berjalan dengan sistem operasi Linux).Teknologi telepon genggam sudah berkonvergensi mengadopsi banyak kemampuan peralatan lain, terutama komputer, sebuah komputer nomaden atau komunikasi komputer mobile. Pavlik menuliskan : "Through convergence, cellular technologies are now built into portable computers, making nomadic computing, or mobile computer communication, a reality."4

Dalam hal teknologi operator jaringan, telepon genggam juga mengalami kemanjuan pesat.teknologi CDMA ( Code Division Multiple Accses) ditemukan unutk yang menemani teknologi GSM ( Global System for Mobile Telecommunication). Selain itu juga ada TDMA (Time Division Multiple Acces) yang tidak begitu populer. Fiturfitur unik juga terintegrasi dengan sebuah telepon genggam seperti layar sentuh, kamera, MP3 player, hingga yang termodifikasi terintegrasi dengan detonator bom), model arus kecepatan data GPRS, EDGE, 3G hingga 3,5 G atau HSDPA, 5 HSUPA, HSPA, HSPA+release 7, teknologi baru $42 \mathrm{Mbps}$ serta LTE (Long Term Evolution) (3,9 G) (4G) yang mampu sekejap mata mengirimkan Video streaming kebelahan bumi lain dengan kecepatan 100 Mbps. 67

Ketika para karyawan perusahaan-perusahaan telepon genggam sibuk mengontrol komputer robot penyolder dan anak-anak fakultas teknik elektro pusing mempelajari komponen-kompenen yang melekat di PCB telepon genggam, sementara perusahaan penyelia jaringan (provider network) banyak membangun disana-sini menara BTS atas pesanan pemegang saham investornya, dan gerai-gerai pulsa bertebaran dipinggiran-pinggiran jalan menjual "candu" (pulsa) suruhan perang tarif di iklan-iklan media massa, apa yang kemudian terjadi di ranah sosial

\footnotetext{
${ }^{3}$ Anonim, "Memori Berkapasitas 512GB, MicroSD Besutan SanDisk", dalam situs http://www.livetekno.com/memoriberkapasitas-512gb-microsd-besutan-sandisk/

${ }^{4}$ John V Pavlik., New Media Technology: Cultural and Commercial Perspectives, (London: Allyn and Bacon, - ), hal. 96.

${ }^{5}$ Rich Ling dan Jonathan Donner, Mobile Communication: Digital Media and Series, (UK: Polity Press, 2009), hal. 41.

${ }^{6}$ AW Subarkah, "Jaringan Seluler LTE: Evolusi yang Menjanjikan”, dalam Surat Kabar Kompas, Senin 17 Mei 2010 , hal 35.

${ }^{7}$ AW Subarkah, "Telekomunikasi Infrastruktur: Ekspektasi Baru dengan Hadirnya LTE”, dalam surat kabar Kompas Rabu 22 Desember 2010., hal 35.
} 
masyarakat dengan masifnya fenomena telepon genggam ini? Pesatnya kemajuan perkembangan teknologi komunikasi dari waktu ke waktu itu yang kemudian memunculkan telepon genggam ini juga berimplikasi dengan dampak-dampak sosial di msayarakat. Ini lah determinisme teknologi, ketika teknologi yang kemudia menjadi faktor penentu dalam pelbagai aspek kehidupan sosial juga kultural, ekonomi dan perpolitikan dalam masyarakat. ${ }^{8}$

Telepon genggam akhirnya tidak saja menjadi sebuah telepon yang fungsinya hanya semata berkomunikasi bertelepon-telepon ria dari 1,4 miliar orang penggunannya, akan tetapi jauh melampaui itu semua. Kecanggihan-kecanggihan yang diintegrasikan kepadanya membuatnya menciptakan "budaya" baru bagi sosial masyarakat. Misalnya telepon genggam tidak lagi sekadar perangkat berkomunikasi, akan tetapi sebagai style (gaya hidup) seseorang, bagian dari pencerminan diri, fungsi diri, dan mungkin status sosial seseorang. Beberapa seri telepon genggam tertentu memang didesian dengan tujuan fungsi tertentu yang mengarah pada sosial prestige seseorang. Harga suatu telepon genggam dengan merk tertentu hanya bisa diraih oleh golongan ekonomi masyarakat tertentu dan ketika dia menentengnya di jalanan yang baginya itu catwalk dengan langkah laksana top model dunia, maka dia sedang menunjukkan "aku dengan telepon genggamku dan hidupku".

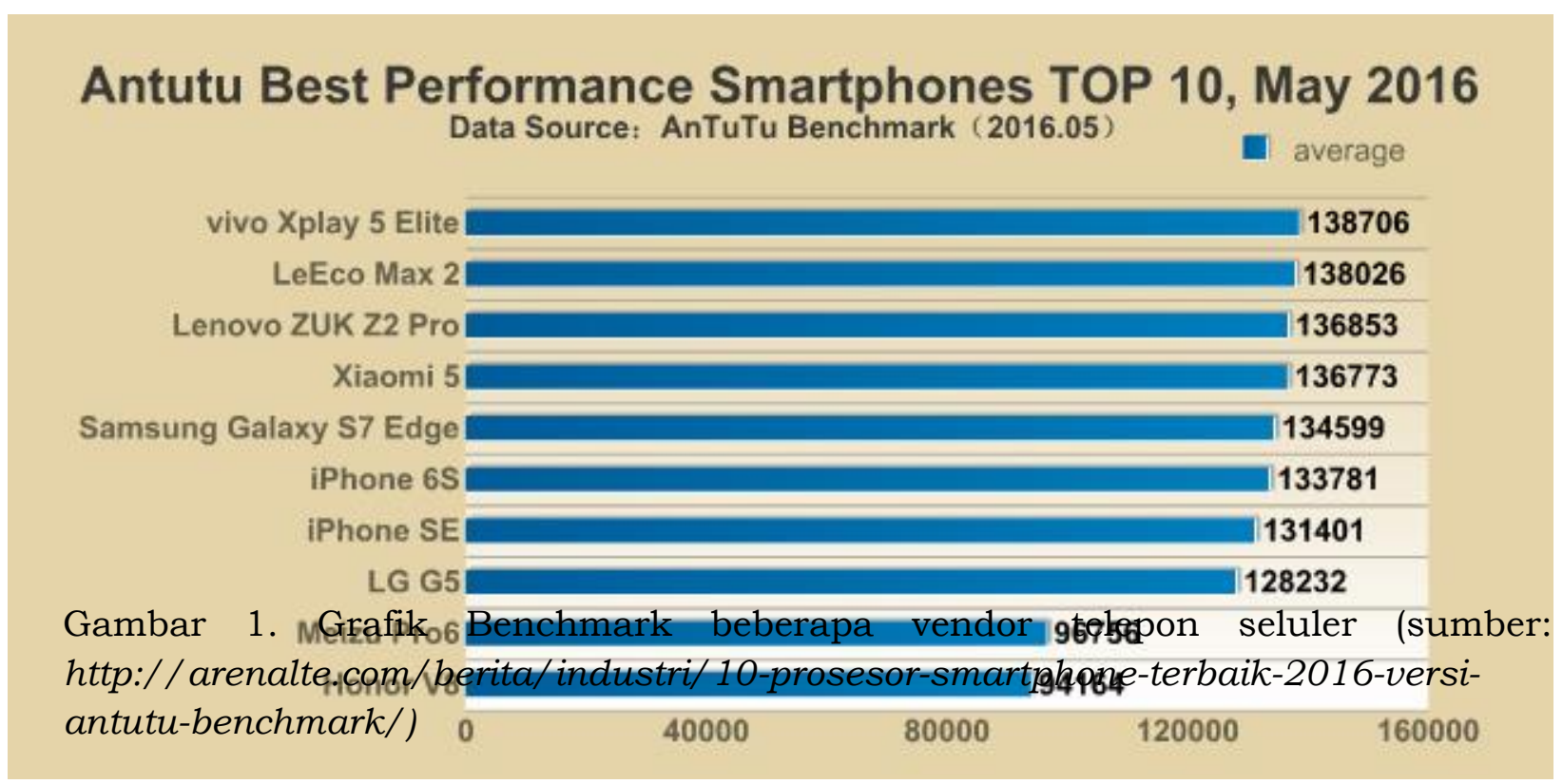

\section{Sejarah Telepon Genggam}

Sejarah telepon genggam memang tidak bisa dilepaskan dari sejarah telepon itu sendiri begitu pula sejarah telepon yang juga tidak bisa dilepaskan dari sejarah teknologi sebelumnya. Akan tetapi pembahasan kali ini akan langsung merujuk pada sejak telepon genggam itu sendiri dengan sedikit akan menyinggung tentang

\footnotetext{
${ }^{8}$ Rob Kitchin, Theoritical Perspective Approaching Cyberspace, (NY: Stone Lake, 1998), hal. 7.
} 
telegraf, karena perusahaan pengembang dua invent itu berkesinambungan. Telegraf pertama kali didemonstrasikan oleh penemunya Samuel Morse pada tahun 1844, tepatnya pada tanggal 24 Mei ketika telekomunikasi elektronik pertama yang mengirimkan pesan "What hath God Wrought?" dari Baltimore ke Washinton D.C. Telegraf membawa banyak perubahan karena mampu memilah makna informasi yang dulunya hanya dapat tersampaikan dengan bantuan transportasi orang atau material. Czitrom menyebutkan : "...information could travel only as fast the messengers who carried it; communication of information and transformation of people and materials were not separated in meaning."

Roger menambahkan : "...telegraph changed all that; a network of lightning lines soon crossed the nation. The electrical messages that crackled along these wires were many times faster than the fastest trains, whose rails the telegraph wires pararelled." 10

Sejarah telepon genggam dimulai sejak dekade pertama di awal abad ke-20, yakni pada tahun 1910, dimana Lars Magnus Ericsson menemukan tunas pertama telepon genggam. ${ }^{11}$ Lars Magnus Ericsson bukanlah pemain baru dalam peran perkembangan telekomunikasi di Eropa. Lars Magnus Ericsson adalah orang berkebangsaan Swedia. Dia sebenarnya adalah orang yang menekuni bidang telegraf. Sesuai dengan namanya, orang Swedia inilah yang mendirikan perusakaan telepon genggam ternama Ericsson, yang dikemudian hari bergandengan dengan perusahaan Asia Sony dan sekarang berubah nama menjadi Sony Ericsson. Sebelumnya perusahaan Ericsson bergerak dibidang telegraf, namun pada masa itu perusahaan ini masih tidak terlalu besar dan tidak menghasilkan profit yang banyak.Berbeda jauh ketika perusahaan Ericsson merambah ke bidang telepon genggam.Tingginya permintaan pasar atas telepon genggam membuat perusahaan memproduksi secara massal dan inilah musim panen baginya.Dengan melihat kondisi di atas dapat diketahui betapa masyarakat sangat bersemangat, meskipun mungkin hanya dinikmati oleh golongan-golongan tertentu saja. ${ }^{12}$

Kemudian pada dekade selanjutnya, yakni pada tahun 1921, penggunaan telepon genggam pertama kalinya digunakan pada suara institusi Negara, yaitu pada unit-unit kendaraan patroli Departemen Kepolisian di Detroit Micthigan. Mobilmobil polisi dikota tersebut sudah dapat berkomunikasi satu dengan mobil lainnya, serta juga dengan operator sentral kepolisian di kantor. ${ }^{13}$

Perkembangan telepon genggam selanjutnya terjadi di Negara Eropa lain, Firlandia. Pada tahun 1960 sebuah perusahaan yang bergerak dibidang perkabelan, Fennis Cable Work, kemudian mengembangkan perusahaannya menjadi perusahaan elektronik yang kemudian perusahaan ini memproduksi suatu brand

\footnotetext{
${ }^{9}$ Daniel J. Czitrom, Media and the American Mind: From Morse to McLuhan, (Chapel Hill: University of North Carolina Press, 1982), hal. 3.

${ }^{10}$ Everette M. Rogers, op. cit. hal. 29

${ }^{11}$ Gerrard Goggin, Cell Phone Culture: Mobile Technology in Everyday Life, (USA: Routledge, 2006), hal. 24.

${ }^{12}$ Fisna Citra Kumala Wardani, "Pengaruh HandPhone Sebagai Media Komunikasi”, dalam situs http://digilib.sunanampel.ac.id/index.php.

${ }^{13}$ Ibid.
} 
telepon genggam ternama didunia, perusahaan ini bernama Nokia.Kemudian pada tahun 1969 sistem telekomunikasi secara resmi dikomersilkan.

Hingga pada tahun 1970-an pasar telepon genggam menjadi semakin marak, terutama di Negara-negara maju di Eropa dan Amerika, seperti Inggris, Perancis, Jerman, Amerika Serikat, Kanada. Saat itu perusahaan yang memproduksi telepon genggam dipegang oleh dua perusahaan besar dan terdapat di Eropa, mereka adalah Motorolla dan Nokia. Sebenarnya dua perusahaan telepon genggam ini masih ada hubungan kerjasama.

Pada awalnya ukuran telepon genggam tidak semungin sekarang dan antenanya lumayan agak panjang, bahkan ada yang mungkin belum tepat disebut telepon genggam karena ukurannya mustahil digenggam tangan, ukurannya sekitar $1 / 2$ meter (panjang) x 1/2 meter (lebar) x 10 sentimeter (tebal). Mungkin oleh sebab itu pada awalnya istilah telepon genggam (handphone) belum digunakan, tetapi mobile telephone atau portable phone

Di Amerika Serikat perusahaan telepon genggam Eropa banyak bekerja sama dengan perusahaan-perusahaan yang ada di kota-kota besar Amerika Serikat, seperti d kota New York dimana perusahaan telepon genggam Motorolla melakukan kerjasama dengan Bell Labs.

Tokoh yang terkenal di perusahaan motorolla ada Dr. Cooper. Copper yang saat itu menjabat sebagai General Manager Communication System Motorola untuk pertama kalinya pada tahun 1973 yang berbicara sendiri sambil berjalan-jalan di sudut-sudut kota New York melalui telepon portable yang dibawanya. Inilah kali pertama khalayak ditunjukkan suatu telepon genggam. Meskipun telepon portable yang dibawa Cooper saat itu masih seberat lengan manusia dewasa itu sendiri, yaitu hampir satu kilogram. Sungguh evolusi yang luar biasa jika dibandingkan dengan ukuran dan massa telepon genggam-telepon genggam jaman sekarang yang hampir seringan setipis sehelai kertas tapi sefungsional suatu komputer kompleks. ${ }^{14}$

Melompat jauh ke perkembangan telekomunikasi ke abad ke 21 ratusan juta masyarakat sudah dapat mengakses dan terkoneksi dengan telepon. 097 menyebutkan: Increased connectivity : mobile sweep the world. The first decade of the twenty-rirst century may be remembered as the historical moment when the majority of the world's population first secured easy and affordable acces to telephone..... there where 1,7 billion telephones on the planet:983 million landlines, and 740 million mobiles. ${ }^{15}$ Jumlah telepon genggam yang digunakan masyarakat dunia pada millenium ini menunjukkan pertumbuhan pengunaan begitu besar akan kebutuhan komunikasi mobile. Disebutkan ditahun 2014 saja dioperkirakan terdapat 6,8 miliar telepon genggam di seluruh dunin dan pada tahun 2015 jumlah ini akan jauh melebihi jumlah populasi penduduk bumi. ${ }^{16}$

\footnotetext{
${ }^{14}$ Fisna Citra Kumala Wardani, op. cit, http://digilib.sunan-ampel.ac.id/download.php?id=34633.

${ }^{15}$ Rich Ling dan Jonathan Donner, op. cit. hal.8.

${ }_{16}$ Anonim, "jumlah ponsel melebihi jumlah manusia", dalam situs http://www.bbc.com/indonesia/majalah/2013/05/130509_iptek_ponsel.
} 


\section{Beberapa Fungsi (Komunkasi) Telepon Genggam Sekarang Ini}

\section{Fungsi Utama Telepon Genggam}

Telepon genggam itu adalah jelmaan dari telepon, sehingga fungsi telepon genggam tidaklah berbeda dengan telepon biasa. Telepon genggam mempunyai fungsi utama untuk menelepon, menghubungkan secara interaktif atau dua arah komunikator dengan komunikan melalui medium perangkat elektronik yang disebut handphone dimana getaran suara ditangkap oleh mikropon kemudian diformulasikan sedemikian rupa melalui kompponen-komponennya lalu dipancarkan (diteruskan) - frekuensi ke perangkat receiver penerima yang kemudian didengar melalui speaker ke si komunikan, dan begitu pula secara bolak-balik proses antara keduanya (komuniator dan komunikan sehingga menjadi komunikasi yang interaktif dua arah.)

\section{Fungsi Ragam Komunikasi pada Telepon Genggam}

Yang dimaksud dengan fungsi ragam komunikasi pada telepon genggam adalah fungsi yang melekat pada telepon genggam yang tujuannya juga untuk berkomuniklasi tetapi dengan cara atau ragam yang berbeda dari fungsi utamanya di atas tadi. Fungsi ragam komunikasi pada telepon genggam erat kaitannya dengan semakin berkembangnya teknologi komunikasi yang mendukung perangkat komunikasi ini. Fungsi ragam komunikasi pada telepon genggam antara lain adalah sebagai berikut :

\section{a. Teks Pesan Singkat}

Teks pesan singkat untuk pertama kalinya muncul pada tahun 1992 (beberapa sumber ada yang menyebutkannya 1991). Teks pesan singkat saat itu diirimkan bukan dari sebuah telepon genggam, akan tetapi sebuah komputer ke telepon genggam pada operator jaringan GSM Vodafone di Inggris. Pada awalnya teknologi pengiriman teks pesan singkat hanya dimiliki oleh operator berbasis GSM, tetapi setelah ditemukan teknologi CDMA, pemgiriman teks pesan singkat akhirnya juga didukung oleh operator yang berbasis CDMA. ${ }^{17}$

Teks pesan singkat terdiri atas 160 karakter huruf atau angka atau simbol dan kombinasinya termasuk juga spasi. Sedangkan kalau bukan merupakan yang termasuk karakter latin maka hanya dibatasi menjadi 70 karakter saja, misalnya karakter Arab atau Cina. Friedhelm Hillebrand, dia menjabat sebagai Kepala/ Pimpinan Non-voice Commite of the Global System for Mobile Communications Group. Seorang pria berkebangsaan Jerman ini pada tahun 1985 duduk di depan mesin ketik kesayangannya lalu meneliti tentang jumlah maksimum sebuah teks pesan singkat. Dalam beberapa kali penulisan teks pesan singkat Hillerbrand selalu menggunakan karakter yang jumlah karakternya kurang dari 160. Kemudian Hillerbrand menetapkan

\footnotetext{
${ }^{17}$ Agus Salim, "Membaca Gerak Komunikasi (SMS) Masyarakat", dalam situs http://www.fokus.co.id/v4/pages/ news.php.
} 
jumlah karakter sebanyak 160 sebagai standar pada seluruh jaringan telepon genggam. 1819

Fungsi ragam komunikasi telepon genggam berupa teks pesan diangkat lazim disebut dengan Short Message Service atau biasa disingkat menjadi SMS. Layanan pesan teks singkat ini menjadifungsi yang sudah dengan sendirinya melekat pada telepon genggam sekarang ini. SMS merupakan fasilitas standar dari sebuah telepon genggam. Sebenarnya teks pesan singkat sudah dikenal sebelumnya, yaitu melalui perangkat pager yang sekarang sudah tidak terdengar lagi 'detak jantungnya' (tidit...tidit...).

Sekitar 85\%-90\% dari 1,4 milair pengguna telepon genggam adalah pengguna layanan teks pesan singkat aktif, dan terus meningkat tiap tahunnya, berbanding lurus dengan menggunungnya tingkat produksi perangkat komunikasi ini. Hampir $100 \%$ dari total pengguna telepon genggam diseluruh Indonesia sejumlah 40 juta lebih adalah pengguna layanan teks pesan singkat aktif, dan juga terus menanjak naik. Dalam kasus Indonesia tidak tanggung-tanggung jumlah teks pesan singkat yang berseliweran dari telepon genggam ke telepon genggam yang lain sekitar 75 juta pesan hanya dalam 24 jam atau 28 miliar pesan dalam satu tahun, 365 hari. Boleh jadi penggunaan teks pesan singkat pada sebuah telepon genggam bisa mengalahkan penggunaan layanan berbasis voice atau suara bertelepon itu sendiri. Menurut beberapa survey yang dilakukan menunjukkan bahwa $95 \%$ pesan teks dikirim hanya dalam tempo 10 detik dan 55\% pengguna telepon genggam diseluruh dunia mengirimkan teks pesan singkat lebh dari satu kali dalam seharinya dengan rata-rata penggunanya sekitar diantara 18 tahun ke atas. Dalam setahun perhitungan kasar laba yang diperoleh operator jaringan telepon genggam adalah sekitar Rp.10.000.000.000.000,00-.20

Layanan teks pesan singkat juga dimanfaatkan oleh kaum pebisnis yang memanfaatkan fasilitas ini. Misalnya melalui program kuis-kuis yang banyak diiklankan di pelbagai media, juga tawaran - tawaran bisnis yang dilakukan melalui tekas pesan singkat, sampai pada tujuan-tujuan jualan content melalui proses pengiriman teks pesan singkat, yang biasanya menyuruh sasarannya dengan ketik "reg_....."

Teks pesan singkat diketik pada tombol-tombol nomor yang juga bertindak sebagai papan pengetikan huruf dengan cara beberapa kali menekannya atau sekarang sudah tersedia dengan papan ketik bertombol huruf alphabet lengkap atau biasa disebut papan ketik QWERTY. Ada jua papan ketik yang menerapkan prinsip layar sentuh atau touch screen, lebih jauh lagi ada telepon genggam yang cara menuliskan huruf-nya juga angka

\footnotetext{
${ }^{18}$ Rahardi, "Sejarah SMS 160 Karakter”, dalam situs http://rajapasar.blogspot.com/2005/06/sejarah-sms.html.

${ }^{19}$ Yan, "Sejarah pembatasan karakter SMS 160 karakter ", dalam situs http://yandevild.multiply.com/ Sejarah pembatasan karakter SMS 160 karakter.

${ }^{20}$ Siti Nur Aryani, "SMS dan Dinamika Komunikasi Massa", dalam Tabloid Trendigital dimuat disitus http://www.trendigital.com/03012006/Techno/Techno.htm. .
} 
atau gambar apapun dengan benar-benar menuliskannya pada layar dan microprosesor canggih pada telepon genggam akan memprosesnya sesuai dengan huruf atau angka dan sebagainya tadi proses ini disebut true imagerecognizing. Bahkan bisa mengenali suara manusia itu sendiri untuk dituliskan dalam bentuk tesk atau perintah, telepon genggam sedemikian hebatnya sudah seperti komputer canggih dengan antar muka voice recognizing dengan manusia, seperti halnya search enggine google yang sudah menerapkan metode ini sebagai input pencariannya. ${ }^{21}$

Teks pesan singkat tidak secara langsung dikirimkan dari sebuah telepon genggam ke telepon genggam lainnya, akan tetapi harus melalui perantara SMSC atau short message service center. Di SMSC pesan akan ditampung dahulu kemudian akan diteruskan ke telepon genggam yang dituju sesuai nomornya, apabila telepon gengam tujuan tidak dalam keadaan aktif, maka teks pesan singkat itu akan disimpan pada SMSC sampai pada validitas waktu maksimumnya yang ditentukan telah habis. Dengan demikian teks pesan singkat tersebut telah gagal disampaikan.

Teks pesan singkat merupakan ragam komunikasi telepon genggam yang mempunyai kekuatan sendiri dalam cara dan pengungkapan informasi yang ingin disampaikan. Misalnya suatu ketika tedapat hal yang tidak mudah diucapkan langsung dengan voice suara dalam telepon, atau juga bisa untuk memperjelas tentang pengejaan suatu kata, pemberitahuan yang sifatnya dapat menunggu hingga saat tujuan nomor telepon genggam aktif dan lain sebagainya.

\section{Internet}

Kalau pada awal ditemukannya internet hanya diperuntukkan untuk mengkoneksikan antar komputer satu dengan komputer yang lainnya dengan bermacam jenis koneksi (wired/berkabel maupun wireless/ tanpa kabel), sekarang ini internet sudah dapat menghubungkan pelbagai macam perangkat, bahkan untuk peralatan rumah tangga sekalipun (misalnya lemari pendingin, kompor gas, yang terhubung ke internet), juga peralatanentertainment seperti televisi, keyboard (musik) dan lain sebagainya. Salah satu kemajuan yang sangat membantu dlam perkebangan telepon genggam adalah dengan ditemukannya teknologi yang bisa menghubungkan internet pada telepon genggam.

Telepon genggam dengan sifatnya yang dinamis, mampu terkoneksi sejauh masih tersedia tersedia jaringan operator penyelianya, berarti pula sejauh itu pula akses internet dapat dinikmati para pengguna telepon genggam.Setelah merambahnya internet ke dalam genggaman tangan ini, kemampuan telepon genggam menjadi semakin super. Internet juga menjadi pendukung baru dalam pengembangan telekomunikasi selular, seperti VoIP

${ }^{21}$ Anonim, "“Ok Google" voice search \& actions", dalam situs https://support.google.com/websearch/answer/2940021? co=GENIE.Platform\%3DAndroid\&hl=en. 
(Voice over Internet Protocol) yang mampu memposisikan internet menjadi jalur baru untuk hubungan ke telepon selular juga telepon rumah. Bermodal model koneksi kecepatan data GPRS, 3,5 G, atau HSDPA, hingga 4G dan LTE, sebuah telepon genggam dapat melakukan banyak hal melalui jaringan luar biasa ini, diantaranya adalah sebagai berikut :

\section{a. MMS}

MMS adalah singkatan dari Multimedia Message Service, yakni layanan operator telepon genggam yang memungknkan penggunanya untuk dapat mengirimkan pesan-pesan multimedia.Pesan multimedia adalah pesan yang kontennya memuat data-data multimedia, seperti gambar (foto), video dan juga audio. Sebenarnya MMS hanyalah sebuah nama yang dimunculkan oleh perusahaan penyelia di Indonesia dan juga mungkin di Negara-negara lain, karena MMS itu sejatinya hanyalah bentuk data yang dikirimkan dengan jaringan internet tadi. Jadi MMS hanyalah data, tetapi bentuknya saja yang berisi konten multimedia dan jalan masuknya melalui mekanisme inbox dan outbox pesan pada telepon genggam.

\section{b. E-Mail}

E-Mail adalah singkatan dari Electronic Mail, yakni surat elektronik. Di dunia internet di perkomputeran E-mail bukan barang baru lagi.Hampir semua orang mempunyai alamat E-mail tertentu. E-mail sudah jelas banyak mempunyai kelebihan dibanding surat biasa dan yang lebih luar biasa lagi bahwa E-mail sekarang sudah bisa di akses melalui telepon genggam yang sudah terhubung ke internet. Pengguna telepon genggam dapat dengan mudah kapan saja, dimana saja selama masih ada jaringan operator telepon genggam dapat memeriksa E-mail masuk, mengetuknya dan membalas Email tersebut.

\section{c. Chat}

Chat atau biasa juga diucapkan sebagai Chatting yang berarti berbincangbincang adalah bentuk komunikasi yang dulu hanya bisa dilakukan didepan sebuah PC atau Laptop. Akan tetapi sekarang sarana komunikasi ini dapat dilakukan dalam genggaman tangan saja. Beberapa vendor persahaan telepon genggam dunia bahkan memproduksi tipe-tipe telepon genggam buat konsumen yang menggila dengan chatting.

Fasilitas chatting biasanya didukung oleh portal-portal atau softwaresoftware tertentu. Seperti pada Yahoo Messagger, Google Talk, hingga jejaring sosial Facebook, Twitter, Whatsapp, Blackberry messenger, Line, Instagram, dll. Pada perkembangannya chatting tidak lagi sebatas teks-teks tulisan saja, melainkan juga dengan dapat bertatap muka langsung dengan lawan bicara atau bahkan dengan mendengar ocehannya langsung melalui video streaming berikut dibawah ini.

\section{d. Video Streaming}

Video streaming adalah metode pengiriman data video secara kontinu (terus-menerus) dengan saat yang bersamaan data video itu dapat langsung 
diputar (dijalankan) sesuai dengan buffering data tersebut.Bahasa gampangnya video streaming adalah moving live broadcast. Metode ini yang memungkinkan penelepon dapat melihat langsung live lawan bicaranya lengkap dengan semua ekspresinya. Video streaming mengandalkan jaringan internet dengan kecepatan tinggi dan bandwidth yang besar, dan ini sudah dapat diatasi dengan teknologi seperti diuraikan diatas sebelumnya. ${ }^{22}$

\section{e. Komunikasi Data}

Komunikasi data yang berjalan melalui jaringan internet sangat dimudahkan dalam hal kecepatan, kecermatan dan keefisienan baik waktu maupun juga keamanannya.Karena data-data dikirimkan melalui paketpaket data yang secara simultan (terus-menerus berkelanjutan) hingga seluruh data sampai ditujuan. Keamananya pun juga terjamin, misalnya dengan metode SSL yang seperti ditetapkan pada mesin-mesina ATM yang secara unik mengkodekan semua paket-paket data sebelum sampai ke alamat tujuan. Dan semua kecanggihan ini terdapat dalam satu telepon genggam. Berikut ini beberapa macam jenis-jenis komunikasi data :

\section{1) Entertainment (Multimedia) Communication Data}

Ini merupakan pengiriman data-data dimana data-data tersebut merupakan file-file multimedia seperti video dan audio atau gambar/image. Komunikasi data entertainment ini bercirikan data-data yangdikirimkan biasanya berukuran cukup besar, misalnya file video yang mencapai puluhan bahkan ratusan $\mathrm{Mb}$ hingga $\mathrm{Gb}$. Misalnya format video dengan kualitas yang bagus tanpa kompresi yang biasanya membuat kualitas gambar suara dan pergerakan segmen-segmennya menjadi halus. Bandingkan dengan teks yang mungkin hanya dalam satuan $\mathrm{Kb}$, misalnya file ber-ekstensi txt, doc, atau rtf. Pada awalnya kendala yang dihadapi oleh sebuah telepon genggam ketika berhadapan dengan komunikasi data-data Multimedia entertainment adalah susah dan lama. Akan tetapi semenjak ditemukannnya GPRS hingga $42 \mathrm{Mb} / \mathrm{s}$ (dan seterusnya) hal ini tidak lagi sulit. Karena semakin menyediakan bandwidth atau lebar data yang cukup lega untuk dilalui data-data tersebut

\section{2) Komunikasi Data Lainnya}

Data-data yang dikomunikasikan, ditransfer disana-sini dalam jaringan internet sangat beragam, mulai dari yang rahasia hingga yang terbuka pada khalayak. Misalnya pada dunia perbankan yang sekarang sudah menerapkan E-banking atau Mobile Banking. Transaksi triliunan rupiah dapat dilakukan hanya dengan mengutak-utik telepon genggam yang sudah terhubung ke internet. Bidang kemiliteran juga memanfaatkan jaringan internet. Boleh jadi keputusan-keputusan penting hanya ditentukan oleh satu tombol kecil saja pada telepon genggam. Hulu-hulu ledak nuklir Amerika Serikat di Alaska yang mengarah ke Rusia bisa saja

${ }^{22}$ AW Subarkah, loc. cit. 
berterbangan dengan mudah di trigger hanya dengan satu instruksi paket data kode-kode dari telepon genggam. Bidang-bidang lain juga bisa menikmati kirim-kiriman data hanya dengan genggaman tangan saja.

\section{Beberapa Fitur Telepon Genggam Sekarang Ini}

Terdapat kecenderungan didunia pertelepon genggaman bahwa telepon genggam yang mutakhir selalu dilengkapi dengan banyak fitur-fitur menarik yang memudahkan banyak pekerjaan dan juga mampu menghibur (mengentertaint) manusia. Fitur-fitur telepon genggam melekat pada seri-seri telepon genggam tertentu yang berkesesuain dengan alasan atau tertuju pada segmen apa model telepon genggam itu dikeluarkan oleh vendor perusaahaannya. Misalnya untuk kalangan orang-orang yang suka mendengarkan musik, maka kemudian vendor Sony Ericsson mengeluarkan seri W....., yang merupakan adopsi nama dari Walkman. Seperti Sony Ericsson W950i.Nokia juga mengeluarkan model dengan jargon Express Music dengan tombol khusus play pada sisi kiri/kanan telepon genggamnya.Ada banyak fitur : Entertainment, bisnis, ibadah, GPS, yang paling berpengaruh dalam hal gaya hidup seseorang adalah mengenai entertimanent. ${ }^{23}$

\section{Camera (video dan photo)}

Telepon genggam berkamera menjadi booming pada awal-awal diperkenalkannya lensa yang sudah terintegrasi dengan telepon genggam. Orang-orang bisa dengan mudah mengabadikan peristiwa-peristiwa penting hanya dengan menenteng telepon genggam yang canggih itu. Mulai dari kamera tingkat biasa (rendah) EGA, VGA, kamera 2 sampai 41 mega pixel (Sony Bob-808), lensa zeis dan lain sebagainya. Telepon genggam berkamera dimulai pada tahun 1999 digunakan di Jepang. Goggin menyebutkan : camera phones have not been existence for long, yet have been popular a leading country for country for camera phone design and use has been japan. The japan manufacture Kyocera marketed the first keitai equipped with a built in camera in july 1999. Called the Visual Phone, Okada recounts tha the PHS VP-210.24

Harga yang ditawarkan juga sangat bervariasi, meski semakin lama semakin bermunculan tipe-tipe baru dengan penyempurnaan di sana-sini membuat harga tipe terdahulu cepat bergeser turun.Telepon genggam yang menyatu dengan kamera berteknologi tinggi dipatok dengan harga selangit. Telepon genggam dengan rate ini hanya dapat dimiliki oleh orang-orang yang berpenghasilan selangit pula.

\footnotetext{
${ }^{23}$ Binar Candra Auni, "Handphone \& Ponsel = Kebutuhan / Gaya Hidup", dalam situs http://hiburan. kompasiana. com/, diakses tanggal 24 April 2010.

${ }^{24}$ Gerrard Goggin, op cit. hal. 144.
} 


\section{Music Player}

Kalau dahulu orang orang menikmati musik hanya di ruangan akustik orkestra atau panggung musik atau studio musik atau ruangan statis tertentu saja sekarang msuik dapat dinikmati dengan ambil melakukan apa saja, sambil apasaja, dimana saja, dan kapan saja. Bermula ketika perusahaan elekrtonik Jepang mengeluarkan Walkman sebagai perangkat yang bisa memainkan musik sambil penikmatnya berjalan-jalan dinamis.Model ini di terapkan pada telepon genggam. Bagi para penikmat musik atau yang hobi mendengarkan audio-audio tertentu menjadi target seri-seri telepon genggam yang mendukung fitur pemutar musik dengan kualitas yang sejernih musik digital Hifi (high fidelity). Vendor-vendor sudah sejak awal mulai melirik pangsa pasar ini, awalnya fitur ini hanya bermula pada ketertarikan membuat ringtone yang lebih indah dengan bunyi music menggantikan bunyi-bunyi sebelumnya yang masih konvensional dan tidak menarik (hingga pada pemutar file Midi saja), kemudian menjelma menjadi perangkat pemutar musik yang khusus.

\section{Game}

Dunia dipenuhi oleh para pencinta-pencinta game-game (permainan).Gamer-gamer juga dimanjakan dengan hadirnya tipe-tipe telepon genggam yang men-support untuk mengaplikasi pelbagai jenis permainan dalam genggaman tangan saja. Nokia 'berjasa besar' dalam memperkenalkan game-game serius (berat) dalam ponsel, awalnya kalangan penikmat game dapat menyalurkan hobi mereka melalui telepon genggam Nokia Engage dan New Engage. Permainan-permainan yang ditawarkan juga sangat beragam dan menarik. Karena telepon genggam mempunyai sistem operasi yang handal seperti Symbian, Blackberry, Windows (bahkan Windows 7 ditanamkan pada vendor ZTE pada tahun 2010), Android, juga Linux, serta berprosesor kencang, maka aplikasi game menjadi sangat kaya, sudah mirip dengan game-game PC (juga game online) yang sangat kompleks dan menarik. Misalnya game-game berat (high spescification modul) seperti Tomb Raider, Need for speed, Dark Enggines, dan masih banyak lagi bertaburan di internet siap di-download dengan menggunaan telepon genggam itu sendiri.

\section{Organizer and Office Application}

Bagi para kalangan yang sibuk dengan pelbagai rutinitas aktifitas seharihari dengan jadwal ketat serta tidak punya banyak waktu untuk mengatur jadwal konvensional blocknote, maka telepon genggam sekarang sudah banyak menyediakan fitur-fitur yang sangat membantu. Seperti aplikasi reminder, note, agenda, alarm, dan lain-lain.Jadi seorang eksekutif yang dinamis dapat membawa kemana saja jadwal hariannya dan dapat melihatnya kapan saja serta juga dapat mengubah dan menyesuaikannya dengan jadwal-jadwal lainnya rutin. Sebenarnya fitur telepon genggam ini sudah pernah ada pada perangkat sebelumnya, yakni PDA. 
Telepon genggam yang sudah dilengkapi dengan papan ketik QWERTY kebanyakan sudah dapat menjalankan aplikasi-aplikasi Office, terutama bagi telepon genggam yang berbasis ssstem operasi Windows. Jadi pengetikan surat di Microsoft Office Word sudah bisa dilakukan di telepon genggam, juga aplikasi-aplikasi Office lainnya seperti Microsoft Office Excell, Microsoft Office Power Point, dan lain-lain.

\section{Dampak terhadap Masyarakat}

Dengan melihat banyaknya kemampuan yang bisa dilakukan hanya dengan alat komunikasi yang mungkin hanya semungil korek api di atas, manusia menjadi sangat dipermudah melakukan banyak hal dalam hidupnya. Manusia jadi semakin bervariasi dalam mengeksprrespikan dirinya. Manusia dapat dengan leluasa memperindah dirinya, bersolek dengan bantuan teknologi sebagai pendamping dan pembentuk image diri. Manusia juga dapat dengan leluasa menempatkan menunjukan dirinya pada level mana dia berada. Selain itu manusia juga dapat dengan mulus mencurahkan keinginan hal-hal negatif dalam dirinya, seperti melakukan tindakan-tindakan kriminal hingga asusila.

Penemuan-penemuan teknologi memberikan kontribusi yang sangat besar dalam membentuk citra kebudayaan dan perubahan kehidupan masyarakat, pola masyarakat berpikir dan cara masyarakat memaknai pengalamanpengalaman yang telah mereka lalui. ${ }^{25}$

\section{Style and Prestige (Gaya Hidup)}

Ada asumsi yang patut diperhatikan bahwa salah satu gaya hidup masyarakat dapat dicerminkan melalui apa yang dikenakannya dalam hal ini adalah telepon genggam yang ditenteng ditangannya. Seseorang yang fashionable sudah pasti dia akan memilih menggunakan telepon genggam yang sesuai (matching) dengan penampilannya. Beberapa vendor memang sengaja membidik bahkan menciptakan masyarakat seperti ini. Sekarang lihat saja Nexian yang mengeluarkan telepon genggam pesolek alias handphone kosmetik seri She NXG788 atau seri edisi khusus dan limited Puteri Indonesia yang penjualannya dipaketkan dengan make up box. ${ }^{26}$ Fisik telepon genggam ini didesain khusus untuk kaum hawa, bentuk casing-nya "pleq" mirip tempat kosmeti (bedak). Dalam iklannya di televisi yang dibintangi oleh Bunga Citra Lestari, telepon genggam,ini di action-kan di depan meja rias. Semakin menguatkan bahwa telepon genggam in segmennya tertuju pada mereka yang memperhatikan penampilan gaya fashion kecantikannya. Telepon genggam menjadi aksesoris tubuh, telepon genggam layaknya pakaian yang dikenakan dengan modisnya zaman. Sehingga tidak aneh kalau banyak dijumpai peragaan-peragaan model yangmelangkah lincah di catwalk dengan berkalungkan telepon genggam. Begitu pula ketika Nokia mengeluarkan seri-seri klasik yangsangat sederhana mulai

\footnotetext{
${ }^{25}$ EM Griffin, A first Look At Communication Theory. Fourth edition, (McGraw: Hill Companies, 2000), hal. 315

${ }^{26}$ Asp, “Cermin Diri di Perangkat Teknologi”, dalam suratkabar Kompas selasa, 12 oktober 2010, hal 13.
} 
dari pemilihan warna bentuk hingga fitir-fitur didalamnya yang cukup sederhana. Juga ada seri-seri Nokia yang ditujukan pada orang-orang yang suka berpetualang outdoor atau para pendaki atau pencinta alam. Tipe-tipe untuk para penghobi tekhnologi juga banyak tersedia seperti seri telepon genggam yang secanggih komputer seperti dituturkan diatas. Seseorang, dialah orang yang modis bergaya feminisme atau gotic, atau adventuirer, atau penggila jejaring sosial di dunia maya, atau orang yang hanya just simple ordinary person. ${ }^{27}$ Tidak selalu patokan untuk memuaskan keinginannya menentukan pilihan untuk mengenakan model tertentu berdasarkan harga atau model, tapi selera seseorang bisa merupakan ketertarikan yang berdasar pada ke khas-an bagi dirinya yang akhirnya menentukan pilihan.

\section{Level(Strata Sosial /Kedudukan Berdasarkan Ekonomi)}

Lex Luthor yang keluar dari mobil mewah Hummer Humvee versi Troops Double Cabin sambil bercakap-cakap dengan telepon genggam Nokia 8910 Special Edition dalam serial TV Smallville yang mengisahkan Superman muda Clack Kent ${ }^{28}$, apa yang dapat diambil kesimpulan dari gadget yang dikenakannya? Hummer yang lapis baja anti RPG dan Nokia mewah yang casingnya berbahan (titanium) sama dengan pelindung peawat ulang-alik NASA anti gesekan panas atmosfir ratusan derajat.

\section{Moral dan Etika}

Perilaku moral dan etika seseorang juga banyak dipengaruhi oleh banyaknya kemudahan kecanggihan yang dimiliki telepon genggam. Negatif atau positifnya perilaku moral seseorang itu semuanya dapat dipenuhi oleh fitur-fitur telepon genggam. Bagi yang berhati malaikat, telepon genggam dimanfaatkan bagi suatu tujuan yang mulia dan baik dengan fungsi telepon genggam sebagai pemermudahnya. Misalnya menyebarkan berita-berita dakwah kebaikan, mengungkapkan rasa peduli atau ucapan selamat atau ucapan lainnya melalui mengirimkan chat atau menelpon, menjalin hubungan baik dan kerjasama dengan relasi dengan terus keep in touch, mempermudah bersilaturrahmi dengan keluarga dan kerabat yang sulit dijangkau dan memerlukan waktu panjang, dan masih banyak lagi.

Sedangkan bagi yang cenderung keiblis-iblisan, kendali penuh juga ada ditangannya. Dari yang menjadi sutradara amatir video tidak senonoh, media asusila, ancaman, penipuan, terorisme, piranti detonator bom, hingga menjadi media transaksi hal-hal illegal (internet bangking).

\section{Feel}

Banyak hal yang dirasa lebih "berasa" dengan hadirnya telepon genggam dengan segala mukjizatnya. Berkomunikasi menjadi lebih hidup dan lebih nyata. Telepon geggam yang sudah dilengkapi dengan fitur-fitur canggih dan didukung

27 Sandy Tias, "Handphone bagi Kehidupan Remaja", dalam situs http://www.ubb.ac.id:80/.

${ }^{28}$ Smallvile, serial TV, season 4. 
oleh kemampuan operator jaringan yang berteknologi tinggi memungkinkan pengguna telepon genggam dapat melangsungkan komunikasi dengan sangat menarik. Kalau pada telepon biasa yang konvensional yang dikomunikasikan hanyalah suaranya saja tanpa melihat wajah atau bahkan badan si lawan bicara (mialnya mimik wajah yang sedang sedih atau gembira atau ekspresi sedang marah -marah dengan tunjuk-menunjukkan tangan), maka telepon genggam yang sekarang sudah jauh melampuai kesederhanaan itu semua. Teknologi komunikasi terbaru sekarang memungkinkan berkomunikasi dengan full body lawan bicara lewat pemproyeksi bentuk 3 dimensi.

Di lain sisi, rasa dengan menggunakan telepon genggam seri-seri jet set atau dengan menentengnya berlalu-lalang di tengah orang banyak dengan tujuan ingin mendapatkan kepuasan dari pengakuan oleh orang yang melihatnya bahwa dirinya orang berduit, maka telepon genggam yang ditentengnya itu sangatlah membantu pembentukan citra yang diinginkannya dapat dirasanya lebih dalam.

\section{Kesehatan}

Meskipun belum mutlak dapat dipastikan bahwa radiasi yang dibawa oleh sinyal frekuensi telepon genggam disebut-sebut memberi kontribusi dalam mengagresifkan sel-sel kangker atau tumor dan dampak kesehatan lainnya, isuisu ini sempat menjadi mencuat di masyarakat dan terus diperdebatkan di kalangan para ahli. Dari sisi bisnis pertumbuhan pemakaian telepon genggam maupun industrinya, rumor ini sedikiot banyak mempunyai pengaruh. Pavlik menyebutkan :

One of the treats to the future growth of the cellular telephone industry is the possible harmful health effects of the cellular phone. Although no clear evidence proving the phones to be safe. Number of lawsuits have been filed against cellular telephone manufacture alleging that heavy use of the phones, which produce an electromagnetic field because of their cellular transmission, causes cancer. In one case, a senior-level scientist at Motorola, one of the leading manufacture of cellular telephone, claims that the testing of a cellular phone that he conducted in 1984 caused him to develop an inoperable and incurable brain tumor. ${ }^{29}$

Baru-baru ini dalam sebuah artikel yang dimuat dalam surat kabar Sin Chew Daily di Singapura, lewat sebuah penelitian menunjukkan bahwa terdapat $80 \%$ orang dari total populasi sampel yang termasuk dalam kategori Cellular Syndrom, seorang ahli psikologi mengatakan bahwa sindrom ponsel adalah dorongan untuk selalu memeriksa atau melirik ada tidaknya panggilan, sms, atau apapun yang berhubungan dengan ponsel tersebut. 30

\footnotetext{
${ }^{29}$ John V. Pavlik., loc. cit.

${ }^{30} \mathrm{Kps}$, “Sindrom Ponsel”, dalam suratkabar Banjarmasin Post, Jum'at 17 Desember 2010.
} 


\section{Simpulan}

Manusia adalah makhluk yang butuh berkomunikasi. Manusia berusaha menciptakan sesuatu yang tujuannya mempermudah dan memperbaikicara dan proses berkomunikasi. Telepon genggam adalah salah satu perangkat komunikasi jauh (telekomunikasi) yang diciptakan melalui serangkaian penemuan-penemuan mulai dari transistor hingga telepon konvensional. Seiringdengan majunya teknologi, teknologi komunikasi juga berkembang. Telepon genggam banyak mengalami perubahan bentuk, fungsi serta nilai.

Telepon genggam kemudian tidak hanya berfungsi sebagai alat berkomunikasi jarak jauh, akan tetapi juga terdapat nilai-nilai yang melekat padanya, misalnya keterwakilan status sosial masyarakat tertentu hingga representasi pencerminan gaya hidup seseorang dalam kesehariannya, seperti kesenangannya, hobby, pekerjaannya, jabatannya, keperluannya hingga positif-negatif perilakunya. Secara tidak langsung meski tidak selalu mewakili sepenuhnya, "HP itu adalah aku dan aku adalah HP".

\section{Referensi}

Buku:

Czitrom, Daniel J.. Media and the American Mind: From Morse to McLuhan. Chapel Hill: University of North Carolina Press. 1982.

Goggin, Gerrard. Cell Phone Culture: Mobile Technology in Everyday Life. USA: Routledge. 2006.

Griffin, EM. A first Look At Communication Theory. Fourth edition. McGraw: Hill Companies. 2000.

Horst, Heather A. dan Daniel Miller. The Cell Phone: And Anthropology of Communication. UK: Biddles Ltd. 2006.

Ling, Rich dan Jonathan Donner. Mobile Communication: Digital Media and Series. UK: Polity Press. 2009.

Littlejohn, Stephen W. Theories Of Human Communication.Thompson: Wardsworth. 2004.

Kitchin, Rob.Theoritical Perspective Approaching Cyberspace. NK: Stone Lake. 1998. Pavlik, John V.. New Media Technology: Cultural and Commercial Perspectives. (London: Allyn and Bacon.

Rogers, Everette M.. Communication Technology: The New Media in Society. London: Collier Macmillan Publisher, 1986

Majalah/Tabloid dan Surat Kabar:

Aryani, Siti Nur. "SMS dan Dinamika Komunikasi Massa", dalam Tabloid Trendigital jugadimuat disitus http://www.trendigital.com/03012006/Techno/Techno.htm. diakses tanggal 24 April 2010.

Asp, "Cermin Diri di Perangkat Teknologi", dalam suratkabar Kompas selasa, 12 oktober 2010, 
Subarkah, AW. "Jaringan Seluler LTE: Evolusi yang Menjanjikan".dalam Surat Kabar Kompas.Senin 17 Mei 2010.

Subarkah, AW. "Telekomunikasi Infrastruktur: Ekspektasi Baru dengan Hadirnya LTE”. dalam surat kabar Kompas Rabu 22 Desember 2010.

Sum. "Sony Ericsson Vivas, Samsung16500U Galaxy, Nokia X6".dalam majalah Pulsa. Mei minggu II 2010

Kps. "Sindrom Ponsel". dalam suratkabar Banjarmasin Post. Jum'at 17 Desember 2010.

\section{Internet :}

Auni, Binar Candra. "Handphone \& Ponsel = Kebutuhan / Gaya Hidup". dalam situs http://hiburan. kompasiana. com/.diakses tanggal 24 April 2010.

Tias, Sandy. "Handphone bagi Kehidupan Remaja".dalam situs http://www.ubb.ac.id:80/.diakses tanggal 24 April 2010.

Wardani, Fisna Citra Kumala."Pengaruh HandPhone Sebagai Media Komunikasi".dalam situs $h t t p: / / d i g i l i b . s u n a n-a m p e l . a c . i d / i n d e x . p h p$.

Anonim, "jumlah ponsel melebihi jumlah manusia", dalam situs http://www.bbc.com/indonesia/majalah/2013/05/130509_iptek_ponsel.

Anonim, "Memori Berkapasitas 512GB, MicroSD Besutan SanDisk", dalam situs http://www.livetekno.com/memori-berkapasitas-512gb-microsd-besutansandisk/

Anonim, ""Ok Google" voice search \& actions", dalam situs https://support.google.com/websearch/answer/2940021?co=GENIE.Platform\%3 DAndroid\&hl=en.

Antutu, "Antutu Report: Top 10 Performance Smartphones, August 2016", dalam situs: http://arenalte.com/berita/industri/ 10-prosesor-smartphone-terbaik-2016versi-antutu-benchmark/ 